\title{
A Review on the Development of Healthcare Infrastructure Through the History of Islamic Civilization
}

\author{
Hussah Hindi Shuja Alotaibi \\ Department of History, College of Arts, \\ Imam Abdulrahman Bin Faisal University, \\ Dammam, 3|44I, Saudi Arabia
}

\begin{abstract}
The current healthcare systems across the world are well established with the use of information and communication technologies. However, the developments of healthcare systems during the early Islamic and medieval ages have contributed to the establishment of various procedures and practices which are still relevant today. In addition, the research related to the history of medicine in the Arab world mainly focused on the medical literature and very few practices; whereas the healthcare infrastructure and management were undermined. In order to address this gap, this study focuses on reviewing the healthcare systems and infrastructural developments through the history of Islamic civilization, which spread across the Middle East, Africa, Spain, and West Asia. The findings are presented systematically under the categories of types of care centers, management and human resources, medical education system, and medical ethics, and then discussed.
\end{abstract}

Keywords: development, healthcare, infrastructure, Islamic civilization

\section{Introduction}

The Islamic revolution started by the Prophet Muhammad in 632 AD has consolidated its gains and established a long period of stability and development in the various regions including the Middle East, North Africa, south-west Europe, and south-west Asia, which have been under the control of various caliphates through the Islamic ages. ${ }^{1}$ Providing care and support to the needy were at the core of Islamic philosophy and accordingly, the Prophet Muhammad reflected the same through his services to the poor and patients. The Prophet himself stated that disability can be treated; as god sent cure in to the world, but not the disease. ${ }^{2,3}$ The Prophet tried to separate medicine from the existing malpractices such as sorcery, and traditional treatments that are not effective. ${ }^{4}$ The caliphs who reigned after the Prophet initiated various developments in the field of healthcare. There are many experts who have excelled in the field of medicine. For instance, Rufayda alAslamiyyah was known to be the first nurse in the medieval period, who treated the wounded soldiers in various battles led by the Prophet Muhammad in the sixth century. ${ }^{5}$ The Abbasid Caliph Harun Al-Rashid during one of his illnesses was not able to be cured by Arab physicians. Later, it was identified that he was cured by an Indian physician using the plant extracts. Fascinated by the expertise of Indian physicians, the caliph encouraged the translations of Indian medical books and encouraged the use of Indian medicines. Accordingly, various Indian medical texts
Correspondence: Hussah Hindi Shuja Alotaibi

Department of History, College of Arts, Imam Abdulrahman Bin Faisal University, King Faisal Road, Dammam, 3144I, Saudi Arabia

Tel +966133330000

Email halotaibi@iau.edu.sa 
were translated to Arabic. Some of the books include Charaka samhita (Kitab-e-Charaka) which was translated to Arabic by Abdullah b. Ali; works of the Indian female gynaecologist Rusa, were translated to Arabic (Kitabe-Rusa fi A'lajat); and Aplanat Indian medicinal book Astangahrdaya was translated by Ibn Nadim. ${ }^{6}$ Though there were studies focusing on the medical literature through the Islamic ages, the aspect of medical infrastructure has been poorly addressed in Islamic history research. $^{7}$ This article aims to review the developments in the healthcare infrastructure during the Islamic civilization.

\section{Preparation of Narrative Review}

Unlike systematic reviews, there is no consensus among the researchers on the standard structure of a narrative review. ${ }^{8}$ As a result, different formats have been followed in defining the approaches followed in preparing review, which may be organised in chronological order, with a summary of the history of research when clear trends are identified, or presented as a "conceptual framework", if the dependent and independent variables and relationships between them are identified. ${ }^{9,10}$ Considering the context of this study, which focuses on the developments of healthcare infrastructure through Islamic civilization, two different approaches may be followed: narrating the developments through the timeline; or categorizing the infrastructural factors and discussing the developments. This study divided the contents into various infrastructural factors including types of care centers, human resources management, medical education system, and medical ethics, and discussed the developments related to these factors. Accordingly various databases including journals related to medicine and Islamic history were searched for relevant articles reflecting the developments in healthcare. A combination of keywords including Islamic history and medicine, healthcare, Islamic civilization and hospitals, Islamic medical literature, and ethics were used for searching relevant articles. In addition, few historical texts and literature, especially sayings from Quran and hadiths were used to interpret the developments in an Islamic context.

\section{Development of Healthcare Infrastructure}

The early evidence of establishing healthcare infrastructure can be related to the Prophet Muhammad, who launched a hospital in in the courtyard of the Prophet's mosque in Medina for treating the wounded soldiers during the Battle of Trench. ${ }^{11}$ The Prophet ordered the assembly of tents for treating the wounded soldiers, the system, which led to the development of mobile clinics with physicians and pharmacists by the later caliphs. ${ }^{12}$ One of the oldest hospitals that was setup in $638 \mathrm{AD}$, bimaristan (hospital) in Khuzestan province of Iran, survived the change of rulers, which is now developed into a public hospital with medical university. ${ }^{13}$ Though, Iran (formerly known as Persia) has led the developments long before Islamic conquests, one of the major developments noticed after the conquest was conservation, consolidation, coordination, and development of ideas and knowledge of medicine in ancient Persian civilization by the Iranian scholars. Scholars including Muhammad ibn Zakariya ar-Razi (854-925 AD) and Ibn Sina (980-1037 AD) were involved in various observations and experiments and contributed much to medical knowledge and literature. ${ }^{14}$ Mansur ibn Ilyas (1390 AD) book, Tashrih al-badan (Anatomy of the body) was one of the famous books that contained structural diagrams of nervous and circulatory systems. ${ }^{15}$ Caliph Al-Walid ibn Abd al-Malik was one of the first caliphs who established hospital in Damascus in 707 AD. The hospital had trained and specialized doctors, nurses, and well-established infrastructure for treating disabled people such as the blind, and separated other patients with contagious diseases such as leprosy. ${ }^{12}$ Similarly, the Prophet was one of the first to lay directives to prevent contamination of various diseases by laying down directives (If you hear about it on a land, do not go ahead of it, and if it falls on a ground while you are on it, do not leave it), which we call as quarantine in the present world. Similarly, Caliph Omar bin Al-Khattab practiced the rules of quarantine for preventing the spread of Emmaus plague in Levant region, resulting in faster control over the spread of epidemic. ${ }^{16}$

There were many factors considered for the establishment of healthcare facilities. Caliphs selected the best sites for establishing healthcare facilities, preferably over the hills or by the river sides in order to ensure the cleaner and secluded environments for the safety of public and for faster recovery of patients. For instance, Al-Adhodi's hospital built by Adhodo al-Dawla was located on the coast of Dejlah river in Baghdad. ${ }^{17}$ Similarly, when Caliph, Haroon AlRashid directed Al-Razi to build a hospital, Al-Razvi selected few places in Baghdad, where he kept few pieces of meat to check the least spoiled one, for identifying the location with best quality of air, ${ }^{17}$ reflecting the efforts 
involved in building the healthcare infrastructure during the early Islamic ages. In addition, Haroon Al-Rashid opened the first free public hospital in Baghdad, and developed an education system for people to learn medicine. He also appointed, efficient professors from across the world including physicians and surgeons for teaching and training medical students, who were issued diplomas after the assessment tests, making them the qualified personnel for medical practice. ${ }^{18}$ Accordingly, another public hospital was opened in Egypt in $872 \mathrm{AD}$, after which the construction of public hospitals has spread all across the Islamic empire from Africa in the west, Spain in the north, to Persia in the east. ${ }^{18}$

There were many hospitals further developed during the medieval Islamic ages in the cities Baghdad, Damascus, Cordoba, Sevilla, and Cairo. There were 60 major hospitals identified in Baghdad and 50 in Cordoba in 1160 by a traveller called Tudela. ${ }^{19}$ One of the advanced hospitals identified during the medieval times was located in Cairo, Egypt, named as Mansuri hospital. It was a selfadministered hospital with separate wards for men and women and also for different diseases, a dispensary, lecture halls, and an out-patient department, a chapel, and a library. Fountains were used to cool down wards. In addition, musicians and story tellers were employed to entertain patients; and at the time of discharge poor patients were given a certain amount of money to manage their immediate expenses, before they could get on to work. ${ }^{19,20}$ Rapid developments were made in developing the healthcare infrastructure during the medieval times, especially under the reign of Umayyad and Abbasid caliphs; while the developments in the healthcare in Europe had been stagnating. Hospitals in Baghdad, Damascus, Cordoba, Sevilla, and Cairo, were also centers for medical education, which have attracted students from Europe and the Far East. ${ }^{21}$

\section{Types of Care Centers}

There were many types of care centers and hospitals that were spread across the Islamic cities during the Islamic civilization, and most of these were operated by using the resources and funds of the endowments under the caliphate. Studies ${ }^{11,22}$ tried to categorise the hospital infrastructure under various types of centers for treating patients, these are discussed below.

\section{Large Hospitals}

The categorization of large hospitals was done by considering various factors such establishment of number of wards separately for men and women, an integrated medical school for education, availability of specialized treatment centers, a well-established infrastructure, etc. As stated earlier the first large hospital in the Islamic civilization was built under the reign of caliph Harun al-Rashid in Baghdad. It was the first city to establish effective healthcare with many large hospitals distributed across the city. Among the noted ones, Sayyida Sayyad Umm al-Khalifah al-Muqtadir hospital was inaugurated on the day of Muharram in 794 AD; Al-Muqtadari hospital built under the reign of Al-Muqtadir, etc. There were five large hospitals in Baghdad city alone by the end of the fourth century. ${ }^{23}$ Endowments from the caliphs were used to build healthcare infrastructure, such as integrated medical neighborhoods, resembling a small city where the care was provided for free. Endowment funds were used for paying for the sick, and doctors, pharmacists and medical students, and also for managing the hospitals. ${ }^{24}$ In Egypt, hospitals were established by the rulers and ministers in different regions. Al-Fateh Ibn Khaqan, Minister of AlMutawakkil Ali God Al-Abbasi and the Emir of Egypt Ahmed Ibn Tulun were few famous personalities who led to the development of healthcare infrastructure in Egypt. ${ }^{22}$ The Emir of Egypt built baths for men and women at a hospital named after him. In addition, hospital established by King Qalawun in Egypt was regarded as one of the most advanced hospitals, with various medicines and service facilities during those times by the traveller Ibn Battuta. $^{25}$

\section{Mobile Clinics}

The mobile clinics were well equipped with medications, instruments, tents, and a staff of doctors, nurses and orderlies. The use of mobile clinics can be assessed from two contexts. Firstly, they included a set of teams sent by the caliphs to remote places such as villages for healthcare inspection and delivery of healthcare services and treat the patients who did not have access to healthcare. ${ }^{22}$ For example, caliph Ali Ibn Isa sent a medical team on a tour of the countryside of southern Iraq to treat the residents, irrespective of their religion, and also their cattle. ${ }^{26}$ Secondly, due to frequent wars during the Islamic civilization, mobile clinics or field hospitals were established for treating the injured soldiers. ${ }^{11}$ As stated previously, the first known mobile clinics were set up using tents by Rufaydah al-Aslamiyah (the first female surgeon in Islamic civilization) during the wars led by the Prophet Muhammad, especially in Battle of the Ditch. ${ }^{27}$ 


\section{Special Hospitals}

There were a few special hospitals built during the Islamic ages. For instance, prison hospitals were built adjacent to the prisons for providing healthcare services to the prisoners, giving them right to access for health. Similarly, specialized hospitals were built for patients with mental illnesses, or contagious diseases such as leprosy. ${ }^{22}$

\section{Management and Human Resources}

Focusing on the patients' management, all the major hospitals during the Islamic ages divided their treatment facilities into two sections: separate wards and treatment facilities for males and females. ${ }^{11}$ Within the wards for males and females, there were separate sections for specific diseases which were monitored by a group of doctors. In addition, health workers were employed to cleanthe hospitals and take care of the elderly and disabled. Workers were employed on both day/night shifts to ensure the delivery of care at any point in time; and also to minimise the burden on healthcare employees. ${ }^{11}$ In addition, large hospitals were not only built to provide access to healthcare, but also for education. All large hospitals were equipped with resources such as libraries, lecture halls, pharmacies, practical rooms for facilitating medical education. ${ }^{13}$ High standards were established in patients' care in the hospitals. Patients were provided with free treatment and care, free food, clean clothes, and were able to stay in hospital until they had fully recovered. ${ }^{17}$ The patients-to-staff ratios were maintained effectively in order to prevent any issues in the delivery of healthcare services. For instance, there were two nurses for one patient at a hospital in Egypt; and overall patient-to-staff ratio in the history compared to current standards was identified to be satisfactory. ${ }^{37}$ In addition, dress code was followed where all the healthcare staff were required to wear clean white clothes. ${ }^{28}$

The hospitals in Islamic ages were considered to be torch bearers for gender equality to other regions in the world. Female physicians and female nurses were employed in hospitals which was identified as a rare scenario in other parts of the world in medieval times. However, it was essential to employ female staff due to the segregation of male and female patients in the hospitals. ${ }^{11}$ Islamic hospitals adopted a unique secular approach in treating all the patients' equally without any discrimination. ${ }^{29}$ In addition, the management of hospitals with such large infrastructure during medieval times reflects the advanced healthcare management skills, which were no less than in the hospitals later built in Europe, such as those built in England during Queen Victoria's era. ${ }^{30}$ For instance, Al-Mansuri hospital was one of the largest hospitals ever built, which had a capacity of 8000 beds with an annual income of one million dirhams (approximately $\$ 275,000$ in current value) collected from endowments. ${ }^{13}$

Similarly, Qalawun hospital in Cairo, Egypt could handle 8000 patients, and equipped with sufficient staff and research personnel. Adequate research facilities were promoted at the hospital to encourage research and lead the developments and innovations in medicine. The hospital was famous for the discovery of the contagious nature of diseases and research into optics and the mechanisms of the eye. ${ }^{11}$ In addition, the hospitals in the Islamic ages were the first to implement competency tests for doctors, drug purity regulations, treatment and service regulations for nurses and interns, and also for advanced surgical procedures. Overall, the efforts and the developments of the Islamic healthcare system since the sixth century were considered to be well-advanced, and accordingly the healthcare system was reflected as: ${ }^{31}$

the extraordinary provision of public bath-houses, complex sanitary systems of drainage (more extensive even than the famous Roman infrastructure), fresh water supplies, and the large and sophisticated urban hospitals, all contributed to the general health of the population.

\section{Medical Education System}

treatment centers but also as medical institutions for imparting medical education and training for students. ${ }^{12}$ They were considered to be the first hospitals to maintain patient records, which were written with the help of students; reviewed and edited by doctors, and were used for future reference for medical students and also for treatment procedures. ${ }^{12}$ A systematic approach in medical education was adopted by awarding academic degrees for students who were later qualified to practice medicine. ${ }^{18,32,33}$ In addition, a system of internship and externship was implemented for residents and student's education. Moreover, eminent physicians such as Al-Razi, Ibn Sina acted as the directors of the medical institutions associated with large hospitals who successfully implemented the practice of clinical training for students along with theoretical education. ${ }^{11}$ Another prominent physician, Ibn Zuhr identified surgery as an independent discipline of medicine and introduced 
a special training course for future surgeons, reflecting the advances in the management of the curriculum. Many physicians and physicists, including Ibn Abi Usaybi'ah and 'Ala ad-Din ibn al-Nafis, were the students of Al-Nuri hospital and medical institutions in Cairo, Egypt. ${ }^{33,34}$

In addition, many scholars have contributed to the medical literature, which was used in the education system. Persian scientist Ali ibn Sahl Rabban al-Tabari's Firdous al-Hikmah ("Paradise of Wisdom") was considered as the first encyclopaedia of medicine in Arabic language, written in seven parts. ${ }^{38}$ Similarly, "Ali ibn al"Abbas al-Majusi's book Kitab al-Maliki, which was later translated by Constantine (The Royal book) was used as a textbook in surgery across Europe. ${ }^{39}$ Muhammad ibn Zakariya al-Razi's contribution to medical literature was greatly acknowledged through his works: Kitab-al Hawi fi al-tibb (Liber continens), ${ }^{40,41}$ Kitab al-Mansuri (Liber ad Almansorem), ${ }^{41}$ Kitab Tibb al-Muluki (Liber Regius), and Kitab al-Jadari wa-l-hasba (De variolis et morbillis). ${ }^{42}$

\section{Medical Ethics}

Medical ethics was identified to be a unique trait of the medieval healthcare system in Islamic civilization compared to their contemporaries. In relation to the access to the treatments, a secularistic approach was followed, where the patients were not discriminated on the basis of their cast, creed, religion, backgrounds, and faith. ${ }^{11}$ The same approach was adopted in employing hospital staff including physicians and other healthcare workers from various communities such as Christians, Jewish, and Hindu backgrounds. Ethical standards were laid down for the physicians in treating the patients by Ishaq bin Ali Rahawi in a treatise called Adab al-Tabib (Conduct of a Physician) in ninth century focusing on various aspects including what the physician must avoid and beware of;

the manners of visitors; the care of Remedy remedies by the physician; the dignity of the medical profession; the examination of physicians; and the removal of corruption among physicians. ${ }^{30}$ Another famous physician, Al-Razvi introduced many progressive ideas targeting the fake doctors and unethical treatment approaches. For instance, Al-Razvi advised doctors to continuously improve their knowledge by studying the advances in the field of medicine and also to indulge in research activities. ${ }^{12}$ Al-Rizvi stated the following in his medical ethics:

The doctor's aim is to do good, even to our enemies, so much more to our friends, and my profession forbids us to do harm to our kindred, as it is instituted for the benefit and welfare of the human race, and God imposed on physicians the oath not to compose mortiferous remedies. $^{35}$

In addition, the approach towards the Islamic healthcare system in the early ages of Islam was mostly influenced by the sayings from Quran and hadiths. For instance, while contemporary societies during the early Islamic ages considered illness as demonic possession or punishment by god, Islamic hospital and healthcare authorities held a different view reflecting sympathy and care towards mentally ill, ${ }^{36}$ which is motivated by saying in Sura 4:5 of the Holy Quran: And do not give the weak-minded your property, which Allah has made a means of sustenance for you, but provide for them with it and clothe them and speak to them words of appropriate kindness. Thus, it can be observed that the medical ethics in the Islamic healthcare system in the early ages was guided by the sayings of the Prophet and hadiths.

\section{Conclusion}

The purpose of this study is to review the healthcare infrastructure through the history of Islamic civilization. Reviewing the types of healthcare centers; the healthcare system has slowly emerged based on the principles of Islam and the needs of the caliphs during the wars for treating wounded soldiers. In addition, large hospitals were used to serve the patients for free of cost, reflecting the motive of healthcare system to serve the people and contribute to their welfare and good health. Special hospitals were developed for serving the poor and differentlyabled, and also to prevent contamination of diseases. The management of the healthcare system reflected effective approaches which are still relevant such as employing day/ night shifts to minimise the burden on healthcare workers, promoting research, integrating hospitals with medical educational institutions, providing quality care without discrimination, ensuring dress codes, and segregation of wards by disease and gender. The efficiency of large hospitals such as Al-Mansuri hospital, Qalawun hospital etc., which have more than 8000-bed capacity, reflected the effective hospital management strategies. Similarly, developments were also made in promoting the medical education, designing curriculum, internship and training programs. Moreover, the medical ethics were identified to be first introduced during the Islamic ages, which are practiced and developed over the time and are still relevant 
in the modern society. Thus, it can be concluded that the developments in the healthcare infrastructure during the early Islamic ages paved the way for various developments in the healthcare system, education, practices, ethics, and management in the latter ages across the world.

There are many implications that can be drawn from the review conducted in this study. Firstly, the principles of healthcare as identified in early Islamic ages were motivated by care, equality, and supporting the needy or disabled. Currently, privatization in healthcare has led to the idea of considering healthcare services as business, with increasing costs for treatment and healthcare services. As a result, irregularities in the access to healthcare is identified, where the poor are considered as unprivileged to healthcare access. Therefore, healthcare should be considered as a service and equal access has to be provided for all. Secondly, the practices of healthy lifestyles (cleanliness, hygiene, healthy diet,a etc.), ethical guidelines and clinical practices, especially physician guidelines written by Islamic scholars can be still relevant today, which have to be adopted in preventing the spread of various diseases such as the recent Covid-19. Thirdly, human resources in healthcare were very effectively managed during the Islamic civilization, meeting the requirements of the population and emergency situations such as wars. However, in the event of pandemics such as Covid-19, the healthcare systems in different countries were on the verge of breakdown. Therefore, the importance of HRM has to be realised by the governments, and measures have to be taken to ensure adequate resources according to the needs of the population and to handle any unexpected events.

\section{Ethical Approval}

The ethical approval was obtained from the Imam Abdulrahman Bin Faisal University.

\section{Funding}

There is no funding to report.

\section{Disclosure}

The author reported no conflicts of interest for this work.

\section{References}

1. Retief FP, Cilliers L. The evolution of hospitals from antiquity to the renaissance. Acta Theologica Supplementum. 2005;7:226.

2. Ghaly MM. Physical and spiritual treatment of disability in Islam: perspectives of early and modern jurists. $J$ Religion Disability Health. 2008;12(2):105-143. doi:10.1080/15228960802160647
3. Al-Asqlani AAH. Fateh Albari Sharwh Sahih Albokhari. Cairo, Egypt: Dar Alrayyan for Heritage. (In Arabic); 1986.

4. Khaldūn I, Giese A. Die Muqaddima: The Muqaddimah. Munich: C. H. Beck: On the history of the world; 2011:391-395.

5. Women and Memory Forum. Women and Islam in the middle ages. Available from: http://english.ahram.org.eg/NewsContent/32/1168/ 77186/Folk/Inspiring-Women/Women-and-Islam-in-the-middle-ages. aspx. Accessed June 7, 2021.

6. Shamsuddin RK. Arabic Teaching and Arabic Literature in Maharashtra_17th_20th Century__with Special Reference to the Influence of Arabic on Marathi. Poona College of Arts Science and Commerce. Savitribai Phule Pune University; 1992.

7. Hamarneh S. Development of Hospitals in Islam. J Hist Med Allied Sci. 1962;XVII(3):366-384. doi:10.1093/jhmas/XVII.3.366

8. Ferrari R. Writing narrative style literature reviews. Med Writing. 2015;24(4):230-235. doi:10.1179/2047480615Z.000000000329

9. Green BN, Johnson CD, Adams A. Writing narrative literature reviews for peer-reviewed journals: secrets of the trade. J Chiropratic Medicine. 2006;5:101-117. doi:10.1016/S0899-3467(07)60142-6

10. Randolph JJ A guide to writing the dissertation literature review. Practical Assessment, Research \& Evaluation 2009;14:1-13.

11. Majali A, Sahar AM. Contribution of Medieval Islam to the Modern Hospital System. Historical Res Lett. 2017;43:23-28.

12. Rahman H, Abdul HH. The development of the Health Sciences and Related Institutions During the First Six Centuries of Islam. ISoIT. 2004;973-984.

13. Miller AC. Jundi-Shapur, bimaristans and the rise of academic centres. $\quad J \quad R \quad$ Soc $\quad$ Med. 2006;99:615-617. doi:10.1177/ 014107680609901208

14. Elgood C. A Medical History of Persia and the Eastern Caliphate from the Earliest Times to the Year 1932 AD 1932. London: Cambridge University Press; 1951:205-209.

15. Turner H. Science in Medieval Islam. Austin: University of Texas Press; 1995.

16. Al-Dhiab AYA Health and Medical Care in the First Hijri Century. Available from: https://www.alukah.net/library/0/31401/. Accessed June 7, 2021.

17. Ghazal A, Sharif K. The Origin of Bimaristans (Hospitals) in Islamic Medical History. Manchester, UK: Foundation for Science, Technology and Civilization (FSTC); 2007.

18. Glubb JB, Short A History of the Arab Peoples; 1969. Available from: http://www.cyberistan.org/islamic/quote2.html\#glubb. Accessed June 7, 2021.

19. Porter R. The Greatest Benefit to Mankind. London: Harper Collins; 1997.

20. Major RH. A History of Medicine. Springfield 111. Charles C. Thomas; 1997.

21. Guthrie D. A History of Medicine. Edinburgh: Thos. Nelson \& Sons; 1958.

22. Zeid AA The role of Islamic endowments in the field of health care; 2015. Available from: https://islamstory.com/ar/artical/23920/. Accessed June 7, 2021.

23. Al-Qifti S-A-D. The Biographies and the Books of the Great Philosophers (1 Ed.). Lebanon: Dar al-Kotob Al-Ilmiyah; 2005.

24. Broadhurst RJC. The Travels of Ibn Jubayr: Being the Chronicle of a Mediaeval Spanish Moor Concerning His Journey to the Egypt of Saladin, the Holy Cities of Arabia, Baghdad the City of the Caliphs, the Latin Kingdom of Jerusalem, and the Norman Kingdom of Sicily. London: Cape; 1952.

25. Grammatico D, Werner L. The Travel Writer Ibn Jubayr. Aramco World. 2015;66:40-43.

26. Crone P. Medieval Islamic Political Thought. Edinburgh, UK: Edinburgh University Press; 2005.

27. Tschanz DW The Islamic Roots of the Modern Hospital; 2017. Available from: https://www.aramcoworld.com/Articles/March-2017/ The-Islamic-Roots-of-the-Modern-Hospital. Accessed June 7, 2021. 
28. Tapper R, McLachlan KS. Technology, Tradition and Survival: Aspects of Material Culture in the Middle East and Central Asia. New York: Routledge; 2003.

29. Nagamia H. Islamic Medicine History and Current Practice. J Int Soc History Islamic Med. 2003;2(4):19-30.

30. Turner HR. Science in Medieval Islam: An Illustrated Introduction. Texas: University of Texas Press; 1997.

31. Savage-Smith E, Pormann PE. Medieval Islamic Medicine. Edinburgh, UK: Edinburgh University Press; 2007.

32. Alatas SF. From Jami ah to University: multiculturalism and Christian-Muslim Dialogue. Current Sociology. 2006;54 (1):112-132. doi:10.1177/0011392106058837

33. Imamuddin SM. Muslim Spain 711-1492 A.D. Leiden: Brill Publishers; 1981.

34. Gibbs HAR, Lewis B, Pellat C, et al. The Encyclopaedia of Islam. 2nd. Leiden: E.J. Brill; 1970.

35. FSTC (Foundation for Science Technology and Civilisation), Islamic Science, the Scholar and Ethics. Available from: http://www.muslim heritage.com/article/islamic-science-scholar-and-ethics. Accessed June 7, 2021.
36. Paladin AV. Ethics and neurology in the Islamic world. Continuity and change. Ital J Neurol Sci. 1998;19(4):255-258. doi:10.1007/ BF02427614

37. Atiyeh M. Arab Hospitals in History. Ann Saudi Med. 1982;2 (2):121-126. doi:10.5144/0256-4947.1982.121

38. Selin H. Encyclopaedia of the history of science, technology, and medicine in non-western cultures. Kluwer. 1997:930.

39. Shoja M, Tubbs R. The history of anatomy in Persia. J Anat. 2007;210(4):359-378. doi:10.1111/j.1469-7580.2007.00711.x

40. Al-Razi TS. Islamic medicine in the 9th century. $J R$ Soc Med. 2006;99(4):206-208. doi:10.1177/014107680609900425

41. Ibn Zakariya RAM The Comprehensive Book on Medicine. Available from: https://www.wdl.org/en/item/9715/. Accessed 19 May 2021.

42. Ar-Razi SF. Geschichte des arabischen Schrifttums Bd. III: MedizinPharmazie - Zoologie - Tierheilkunde = History of the Arabic literature Vol. III: Medicine - Pharmacology - Veterinary Medicine. Leiden: E. J. Brill; 1970:276, 283.
Journal of Healthcare Leadership

\section{Publish your work in this journal}

The Journal of Healthcare Leadership is an international, peer-reviewed, open access journal focusing on leadership for the health profession. The journal is committed to the rapid publication of research focusing on but not limited to: Healthcare policy and law;Theoretical and practical aspects healthcare delivery; Interactions between healthcare and society and evidence-based practices; Interdisciplinary decision-making;

\section{Dovepress}

Philosophical and ethical issues; Hazard management; Research and opinion for health leadership; Leadership assessment. The manuscript management system is completely online and includes a very quick and fair peer-review system. Visit http://www.dovepress.com/ testimonials.php to read real quotes from published authors. 